\title{
帯関数モデル形一対比較法のための 数値処理法とその解領域
}

\author{
小林 涁* ・坂 本 泰 彦*
}

\author{
A New Solving Method for Paired Comparison Method Based \\ on Band Function Model and It's Solution Domain
}

Akira KoBAYASHI* and Yasuhiko SAKAmoto*

This paper proposes a new method of constructing interval scales from numerical data obtained by paired comparisons. This method is based on band function model.

Band function model has been suggested by Kobayashi and Shibata to construct a reasonable interval scale. However, Kobayashi-Shibata's iterative algorithm gives only one scale of various scales which should be given as solutions, and the accuracy is affected by the choice of initial value.

First, the authors explain that information contained in paired comparisons data can be transformed reasonably into simultaneous homogeneous linear inequalities.

Next, effective algorithm is introduced to solve the inequalities to obtain interval scales. The solution domain is given as a set of inner points of a polyhedral convex cone, and expressed with a set of edge vectors. As the extent of the solution domain indicates the fuzziness, further discussion on precision has become able to be done.

This method is compared with KobayashiShibata's method, and the solution of the latter method is shown to be located a step inside of the boundary of this method's solution domain.

Finally, the proposed method is applied to the experimental data obtained from subjective comparisons of weights. The obtained interval scale shows good agreement with the real weighing scale.

Keyword : band function model, paired comparisons, linear inequalities, solution domain, sensory evaluation

$\dagger$ 第 17 回計測自動制御学会学術講演会で発表 (昭 53・8)

* 東京工業大学工学部 東京都目黒区大岡山 2-12-1

* Faculty of Engineering, Tokyo Institute of

Technology, Meguro-ku, Tokyo

(Received September 4, 1981)

\section{1. まえがき}

近年, 計測工学の中で, 官能検査の占める重要性が 指摘されている12,2). 乙の分野で用いられる各種測定 法の中で, 一対比較法は高精度の間隔尺度構成法とし て認識され，よく用いられている ${ }^{3)}$. 一対比較データ の数值処理法としては, 比較判断の構造としてどのよ うなモデルを仮定するかにより，さまざまの方法が考 えられるが中でも Scheffé の方法, Thurstone の方 法はよく用いられているようである.てれらの方法 は，手計算で解が求まる簡便さが大きな利点である が，比較判断の基本的性格として直線性を仮定してい る.このため，より実態に則した一般的なモデルに基 づく数值処理法が望まれる. 特に, 近年計算機の発達 により，計算量に対する制約が大幅に緩められている ことを考えると，乙の分野について工学的に再考する ことは有意義であろう.

一方，小林・芝田によって提案された帯関数モデ ル4)は，従来のほとんどのモデルを包括的に含むむの で，広い適用範囲をむつと考えられる．そこにおいて は，ある適当な評価関数が定められ，最急降下法によ り逐次的に評価関数が零になるような間隔尺度值が 1 組求められているが，評価関数を零にする解はユニー クではなく，ある広がり（解領域）をむつととが示唆 されている4). 本論文は，带関数モデルに基づき，そ の解領域を余さず求める方法に関するむのである.

この方法は，モデルの柔軟さから，

(i) 比較判断に非直線性があってもよい

（ii）必ずしむすべての比較対の判断結果を必要之 しない

という長所をむつほか

（iii） 判断結果に入っているあいまいさやバラッキ の程度を不感帯幅の大きさとして知ることがで 
きる

（iv）解を領域で与えるため，あいまいさの議論が 詳しくできる可能性を有する

という特長を備えている.

以下では，帯関数モデルの概略と解領域を求める数 值解法アルゴリズムを説明し，さらに重さの一対比較 データに適用した例を示しながら本アルゴリズムの性 質を考察し，その効用について述べる.

\section{2. 帯関数モデルと連立同次線形不等式}

\section{1 帯関数モデル ${ }^{4)}$}

$N$ 個の対象を考え，その可能な対に関して一対比較 判断を行うむのとする．乙の場合，各対象 $X_{i}$ に対応 して仮想的に考えた心理的尺度を $m_{i}$ とし， $X_{i}$ に対 する $X_{j}$ の比較判断の結果を数值的に $\varphi_{i j}$ で表わす. このとき, $\varphi_{i j}$ と $m_{i}, m_{j}$ との間にはつぎの関係があ るむのと考える.

$$
\begin{array}{r}
f_{d}\left(m_{j}-m_{i}\right) \leqq \varphi_{i j} \leqq f_{u}\left(m_{j}-m_{i}\right) \\
i, j \in\{1,2, \cdots, N\}
\end{array}
$$

ここで $f_{d}(d), f_{u}(d)$ は共に $d$ に関するある単調増加 関数である.

(1)式において $f_{d}(d)$ と $f_{u}(d)$ とに狭まれる領域 は比較判断に含まれるあいまいさやバラッキの範囲を 表現し，また $f_{d}(d)$ と $f_{u}(d)$ が単調増加関数である ことによって比較判断の平均的性格は $m_{j}-m_{i}$ と単 調増加関係にあることが表現される。

われわれの目標は最終的に適切な $m_{i}$ を決定するこ とにあるが，われわれが最初手にするデータは $\varphi_{i j}$ だ けであり, $f_{d}(d)$ や $f_{u}(d)$ についても単調増加性以 外なんの前提む仮定していない. $\varphi_{i j}$ と $f_{d}(d), f_{u}(d)$ の単調増加性のみから出発して, 適切な $m_{i}$ を求める 方法を与えるととが本論文の目的である.

\section{2 不等式の導出}

（1）帯関数の幅が零の場合

まず説明をわかりやすくするために，(1)式におい て $f_{d}(d)$ と $f_{u}(d)$ の差が小さくなり, 零になった極限 を考える，乙の場合，(1)式はつぎのように書ける.

$$
\varphi_{i j}=f\left(m_{j}-m_{i}\right) ; i, j \in\{1, \cdots, N\}
$$

$f(d): d$ 亿関する単調増加関数

(2)式に従って $m_{i}, m_{j}$ から $\left\{\varphi_{i}\right\}$ が決定される際, $f(d)$ として異なる関数形を想定すれば， $\varphi_{i j}$ そのも のの数值は変わるが, 単調増加関数であるので $\varphi_{i j}$ の 大小関係は保存される，逆に，与えられた $\varphi_{i j}$ からわ れわれが得ることのできる $m_{i}$ に関する情報は，単調 増加性以外 $f(d)$ は未知であるがゆえにつぎのよう な不等式のみである.

$$
\begin{aligned}
\varphi_{q r}<\varphi_{s t} & \Longleftrightarrow f\left(m_{r}-m_{q}\right)<f\left(m_{t}-m_{s}\right) \\
& \Longleftrightarrow m_{q}-m_{r}<m_{t}-m_{s} \\
& \Longleftrightarrow-m_{q}+m_{r}+m_{s}-m_{t}<0
\end{aligned}
$$

$\varphi_{i j}$ のすべての対について $(3)$ 式のような不等式を得 れば，われわれは帯関数モデルの仮定のもとに， $\varphi_{i j}$ から得られるすべての情報を $m_{i}$ に関する連立不等式 に変換したことになる，すなわち，つぎのような連立 同次線形不等式が一対比較判断から得られる最大限の 情報である。

$$
\left\{\begin{array}{c}
-m_{q_{1}}+m_{r_{1}}+m_{s_{1}}-m_{t_{1}}<0 \\
-m_{q_{2}}+m_{r_{2}}+m_{s_{2}}-m_{t_{2}}<0 \\
\vdots \\
-m_{q_{K}}+m_{r_{K}}+m_{s_{K}}-m_{t_{K}}<0
\end{array}\right.
$$

$K$ : 大小関係の成立する $\varphi_{i j}$ の対の数

結局，心理的尺度 $m_{i}$ は (4) 式を満たすすのとして与 えられるが，間隔尺度では原点と単位の取り方に任意 性があるので，一般性を失うことなくつぎの条件を付 け加える。

$$
\begin{aligned}
& \sum_{i=1}^{N} m_{i}=0 \\
& \sum_{i=1}^{N} m_{i}{ }^{2}=1
\end{aligned}
$$

以上により, 問題は (4)〜 (6) 式の連立式を解くこと に帰着される。

（2）帯関数に幅がある場合

つぎに，判断にバラッキやあいまいさがある場合に 対応して帯関数が幅をむつ場合を考える，便宜上，带 関数の $\varphi_{i j}$ 軸方向の幅 $w(d)$ を次式で表わすととに する。

$$
w(d)=f_{u}(d)-f_{d}(d)
$$
このとき，ある $\varphi_{q r}$ に注目し，ほかの $\varphi_{i j}$ との大小 関係から $m_{i}$ に関する不等式をどのように導けばよい か考察する (Fig. 1 参照). Fig. 1 において，実際 $\varphi_{q r}$ が $f_{d}\left(m_{r}-m_{q}\right)$ から $f_{u}\left(m_{r}-m_{q}\right)$ の間のどの位置 に布置するかは不明であるため， $\varphi_{q r}$ との差が $\varepsilon\left(m_{r}-\right.$ $\left.m_{q}\right)$ より小さい $\varphi_{s t}, \varphi_{s}{ }^{\prime}{ }^{\prime}$ に関して次式の関係が成 立している場合がありうる。

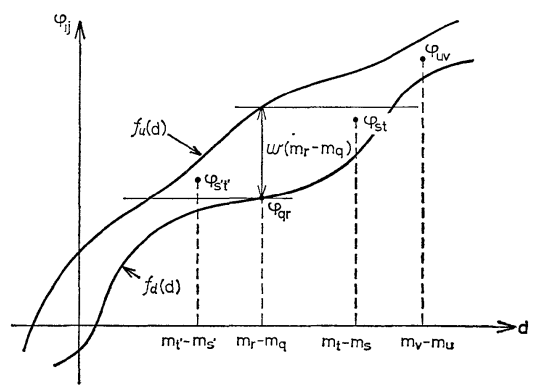

Fig. 1 Band function model for paired comparisons 


$$
\begin{aligned}
& \left\{\begin{array}{l}
0<\varphi_{s^{\prime} t^{\prime}}-\varphi_{q r}<\varepsilon\left(m_{r}-m_{q}\right) \\
m_{r}-m_{q}>m_{t^{\prime}}-m_{s^{\prime}}
\end{array}\right. \\
& \left\{\begin{array}{l}
0<\varphi_{s t}-\varphi_{q r}<\varepsilon\left(m_{r}-m_{q}\right) \\
m_{r}-m_{q}<m_{t}-m_{s}
\end{array}\right.
\end{aligned}
$$

(8)，（9)式からわかるように，上述の状況において $\varphi_{i j}$ 間の大小関係から $m_{i}$ に関する不等式の不等号の 向きは一意的に決まらないので，乙のままでは（3)式 をいきなり適用するととはできない，一方， $\varphi_{q r}$ との 差が $w\left(m_{r}-m_{q}\right)$ よりあ大きい $\varphi_{u v}$ については, (3) 式に準じたつぎの不等式が成立する(注 1 ).

$$
\varphi_{q r}+w\left(m_{r}-m_{q}\right)<\varphi_{u v} \Longrightarrow m_{r}-m_{q}<m_{v}-m_{u}
$$

ところで，われわれには $f_{d}(d), f_{u}(d)$ の関数形は 未知であるから $w(d)$ 屯未知である. そこで, $w(d)$ の代りに非負の実定数 $\varepsilon$ を導入し，(10)式の代りにつ ぎの(11)式に基づいて $m_{i}$ に関する不等式をたてる.

$$
\varphi_{q r}+\varepsilon<\varphi_{u v} \Longrightarrow m_{r}-m_{q}<m_{v}-m_{u}
$$

このとき，むし $\varepsilon$ の值が小さすぎれば（８)式に対応す るケースが生じ，不等号の向きが互いに逆転した不等 式が得られるため, ほかの不等式と連立させた解は空 集合になるであろう。をを大きくしていけば，そのよ うな不等式は順次取り除かれ，やがて，不等号が逆転 した不等式はすべて取り除かれる. そして， $\varepsilon$ が $\varepsilon_{\max }$ 以上になれば，連立不等式は $m_{i}$ の真值を内点に含む 解領域を与える。ただし $\varepsilon_{\max }$ は

$$
\varepsilon_{\max }=\max _{d} w(d)
$$

である。

そこで， $\varepsilon$ の値を漸増させては(11)式に従って $m_{i}$ に関する連立不等式を導出し，その連立不等式が解を むつような最小の $\varepsilon$ の值 $\varepsilon^{*}$ を用いて $m_{i}$ を求める アルゴリズムが考えられる。（ $\varepsilon^{*}$ と $\varepsilon_{\max }$ との関係に ついては，5章で適用例を示しながら説明する.）

結局，乙の場合にも問題はつぎの連立式を解くこと に帰着される。

$$
\left\{\begin{array}{l}
\sum_{i=1}^{N} m_{i}=0 \\
\sum_{i=1}^{N} m_{i}^{2}=1 \\
-m_{q_{k}}+m_{r_{k}}+m_{s_{k}}-m_{t_{k}}<0 ; k \in\{1, \cdots, K\}
\end{array}\right.
$$

(注 1) $\varphi_{q r}$ より小さい $\varphi_{w x}$ については, (10) 式の代りに 次式を用いる.

$\varphi_{q r}-w\left(m_{r}-m_{q}\right)>\varphi_{w x} \Rightarrow m_{r}-m_{q}>m_{x}-m_{w}$
(注 2) $\sum_{i=1}^{N} m_{i}=0$ より未知数を一つ消去すれば, (15)式は $N-1$ 次元の同次線形連立不等式になる. 同次線形連 立不等式の性質などについては文献 5) による.

$$
\begin{gathered}
\text { ただし，(13) 式は } \\
\varphi_{q_{k} r_{k}}+\varepsilon^{*}<\varphi_{s_{k} t_{k}}
\end{gathered}
$$

なる関係にある対象 $X_{q_{k}}, X_{r_{k}}, X_{s_{k}}, X_{t_{k}}$ の組すべてに ついて立てられた連立不等式であり，Kはその連立不 等式の個数である.

\section{3. 解領域と解法のアルゴリズム (注 2)}

\section{1 解領域}

(13)式の連立不等式を, 行列を用いて表現すると次 式となる。

$$
A \boldsymbol{m}=\left(\begin{array}{c}
\boldsymbol{a}_{1} \\
\boldsymbol{a}_{2} \\
\vdots \\
\boldsymbol{a}_{K}
\end{array}\right)\left(\begin{array}{c}
m_{1} \\
\vdots \\
m_{N}
\end{array}\right)<0
$$

$$
A: K \times N \text { 行例, } \begin{array}{r}
\boldsymbol{a}_{k}: N \text { 次元横ベクトル } \\
\boldsymbol{m}: N \text { 次元縦ベクトル }
\end{array}
$$

$A$ 係数行列， $\boldsymbol{a}_{k}$ を係数ベクトルと呼ぶこととする.

また，(5)，(6)式を(16)，(17) 式に書き換える.

$$
\begin{aligned}
& \boldsymbol{a}_{0} \cdot \boldsymbol{m}=(1,1 \cdots 1) \cdot \boldsymbol{m}=0 \\
& \boldsymbol{m}^{t} \cdot \boldsymbol{m}=1
\end{aligned}
$$

(13)，(16)式より次式が成立することは容易にわかる.

$$
\boldsymbol{a}_{k} \cdot \boldsymbol{a}_{0}{ }^{t}=0 ; k \in\{1, \cdots, K\}
$$

すなわち

$$
\operatorname{rank} A \leqq N-1
$$

さらに，連立不等式の物理的意味を考えて (20)式が成 立しているものとする.

rank $A=N-1$

$$
\text { さて, (15)式の中の一つの式 }
$$

$$
\boldsymbol{a}_{k} \cdot \boldsymbol{m}<0
$$

の解は， $N$ 次元ユークリッド空間内で原点をとおり $\boldsymbol{a}_{k}$ と直交する超平面によって定まる一つの開半空間 である. (15) 式の解はこれら $K$ 個の共通部分である. さらに(16)式を連立させた解は（(20) 式の性質む考慮 すると), 解が存在すれば, 原点を頂点とするある凸 多面錐の内点全体になる.

この凸多面錐の各稜上に終点を取り，原点を始点之 したベクトルを稜ベクトルと呼び， $\boldsymbol{g}_{i} ; i \in\{1, \cdots, r\}$ で表わす.また， $\boldsymbol{a}_{k} ; k \in\{1, \cdots, K\}$ の中から，ほか の係数ベクトルの非負線形結合では表わせないものを 抜き出し，改めて $\boldsymbol{h}_{j} ; j \in\{1, \cdots, s\}$ と表わす.する と，(15)，(16)式の解領域は連立不等式に関する性質 よりつぎのように表現できる5).

$$
\begin{aligned}
& \left\{\boldsymbol{m} \mid \boldsymbol{a}_{0} \cdot \boldsymbol{m}=0, \quad \text { Am }<0\right\} \\
& \quad=\left\{\boldsymbol{m} \mid \boldsymbol{a}_{0} \cdot \boldsymbol{m}=0, \quad H \boldsymbol{m}<0\right\} \\
& \quad=\left\{\boldsymbol{m} \mid \boldsymbol{m}=\sum_{i=1}^{r} \lambda_{i} \boldsymbol{g}_{i}, \quad \lambda_{i}>0\right\}
\end{aligned}
$$

ただし 


$$
H=\left(\begin{array}{c}
\boldsymbol{h}_{1} \\
\vdots \\
\boldsymbol{h}_{s}
\end{array}\right)
$$

ここで $\boldsymbol{h}_{j}$ が現れる理由はつぎのように説明で きる、すなわち，一般に，連立不等式には冗長 な不等式が含まれている，たとえば，

$$
\left\{\begin{array}{l}
\boldsymbol{a}_{1} \cdot \boldsymbol{m}=-m_{1}+m_{2}+m_{3}-m_{4}<0 \\
\boldsymbol{a}_{2} \cdot \boldsymbol{m}=-m_{2}+m_{4}+m_{5}-m_{6}<0
\end{array}\right.
$$

なる三つの不等式が与えられているとすると，

(25) 式は (23)，（24) 式の各辺をそれぞれ加え合 せるととにより導出されるから，(25)式はこの 連立不等式加ら取り除いても差し支えない。 (ただし (25) 式と (24) 式から(23) 式を，あるい は(25)式と (23) 式から (24) 式を導出することは できず，取り除く不等式が一意に決まる点は， 連立方程式と異なる点であり注意を要する，と の点は，つぎの係数べクトルの正線形結合性の 所にも関連する)．乙のとき， $\boldsymbol{a}_{3}$ は $\boldsymbol{a}_{1}$ と $\boldsymbol{a}_{2}$ の 正線形結合で表現できる，A からH を抜き出 すととは，(15)式のうち壳長な不等式を取り除 いて解領域の決定に必要十分な不等式を抜き出 すととに相当する．そこで， $\boldsymbol{h}_{j}$ を必要十分係 数ベクトルと乎ぶ. また，一つの $\boldsymbol{h}_{j}$ は，解を 定める凸多面錐の一つの辺 (face) を定めてい る.

なお，(17) 式は解が原点から距離 1 の超球面 上にあることを示している，そこで，稜ベクトルも長 さ1に正規化する.

$$
\left\|\boldsymbol{g}_{i}\right\|=1 ; i \in\{1, \cdots, r\}
$$

\section{2 解法のアルゴリズム}

本節では, 前節で定義した表記法を用いて (15), (16) 式の連立式を解くアルゴリズムについて述べる.

まず，(16)式と，Aの $n$ 行目までの不等式を連立さ せたときの解領域がつぎのように $\left\{{ }^{n} \boldsymbol{g}_{i}\right\},\left\{{ }^{n} \boldsymbol{h}_{j}\right\}$ によ って与えられていたとする.

$$
\begin{aligned}
& \left\{\boldsymbol{m} \mid \boldsymbol{a}_{0} \cdot \boldsymbol{m}=0, \quad \boldsymbol{a}_{k} \cdot \boldsymbol{m}<0 ; k \in\{1, \cdots, n\}\right\} \\
& =\left\{\boldsymbol{m} \mid \boldsymbol{a}_{0} \cdot \boldsymbol{m}=0,{ }^{n} \boldsymbol{h}_{j} \cdot \boldsymbol{m}<0 ; j \in\left\{1, \cdots, s_{n}\right\}\right\} \\
& =\left\{\boldsymbol{m} \mid \boldsymbol{m}=\sum_{i=1}^{r_{n}} \lambda_{i}{ }^{n} \boldsymbol{g}_{i}, \quad \lambda_{i}>0 ; i \in\left\{1, \cdots, r_{n}\right\}\right\}
\end{aligned}
$$

このとき, $n+1$ 行目の不等式 $\boldsymbol{a}_{n+1} \cdot \boldsymbol{m}<0$ を付け加 えて得られる解領域を規定する $\left\{{ }^{n+1} \boldsymbol{g}_{i}\right\},\left\{{ }^{n+1} \boldsymbol{h}_{j}\right\}$ は, 以下の手順に従って与えられる.

$1^{\circ} \quad p_{i}=\boldsymbol{a}_{n+1} \cdot{ }^{n} \boldsymbol{g}_{i} ; i \in\left\{1, \cdots r_{n}\right\}$ を求め, ${ }^{n} \boldsymbol{g}_{i}$ を $p_{i}$ が負，零，正になることで分類し，それぞれ ${ }^{n} \boldsymbol{g}_{i}{ }^{-}$, ${ }^{n} \boldsymbol{g}_{i}{ }^{0},{ }^{n} \boldsymbol{g}_{i}+$ と書き改める.
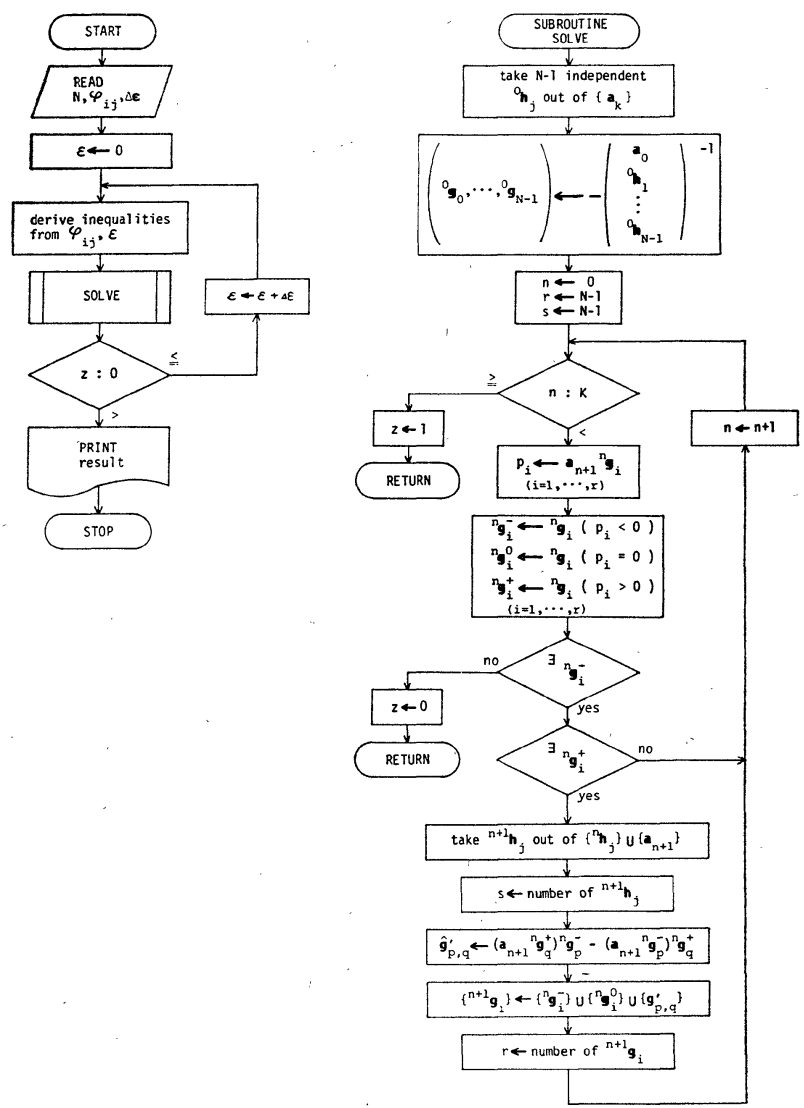

Fig. 2 Flowchart of proposed method

$2^{\circ}$

(2A) $\left\{{ }^{n} \boldsymbol{g}_{i}-\right\}$ が空集合の場合

それまでの解領域内部の任意の点 $\boldsymbol{m}$ に対し 次式が成立するとととなり，解は空集合とな 万。

$$
\begin{aligned}
\boldsymbol{a}_{n+1} \cdot \boldsymbol{m}= & \boldsymbol{a}_{n+1} \sum_{i=1}^{r_{n}} \lambda_{i}{ }^{n} \boldsymbol{g}_{i} \\
= & \sum_{i=1}^{r_{n}} \lambda_{i}\left(\boldsymbol{a}_{n+1}{ }^{n} \boldsymbol{g}_{i}\right) \geqq 0 \\
& \lambda_{i}>0 ; i \in\left\{1, \cdots, r_{n}\right\}
\end{aligned}
$$

(結局，2章 2 項で述べたように $\varepsilon$ が小さす ぎたのだから，をを増加させて不等式をたて るととからやり直す.)

(2B) $\left\{{ }^{n} \boldsymbol{g}_{i}-\right\}$ が空でなく, $\left\{{ }^{n} \boldsymbol{g}_{i}{ }^{+}\right\}$が空集合の場合 それまでの解領域は $\boldsymbol{a}_{n+1} \cdot \boldsymbol{m}<0$ の定める開 半空間の内部にあるので $\boldsymbol{a}_{n+1}$ は圥長な係数 ベクトルである. 結局, 解領域は変更されず

$$
\left.\begin{array}{l}
{ }^{n+1} \boldsymbol{g}_{i}={ }^{n} \boldsymbol{g}_{i} ; i \in\left\{1, \cdots r_{n}\right\}, \quad r_{n+1}=r_{n} \\
{ }^{n+1} \boldsymbol{h}_{j}={ }^{n} \boldsymbol{h}_{j} ; j \in\left\{1, \cdots, s_{n}\right\}, s_{n+1}=s_{n}
\end{array}\right\}
$$


である.

(2C) $\left\{{ }^{n} \boldsymbol{g}_{i}-\right\}, \quad\left\{{ }^{n} \boldsymbol{g}_{i}{ }^{+}\right\}$が共に空集合でない場合 それまでの解領域は $\boldsymbol{a}_{n+1}$ に直交する超平面 で 2 分される. どの ${ }^{n} \boldsymbol{g}_{i}{ }^{-}$とも直交しない ${ }^{n} \boldsymbol{h}_{j}$ は変更後の解領域を規定する凸多面錐の いずれの辺をむ定めるものとはなり得ないの で取り除き， $\left\{{ }^{n+1} \boldsymbol{h}_{j}\right\}$ はつぎのようになる. $\left\{{ }^{n+1} \boldsymbol{h}_{j}\right\}=\boldsymbol{a}_{n+1} \cup\left\{\boldsymbol{h} \mid \boldsymbol{h} \in\left\{{ }^{n} \boldsymbol{h}_{j}\right\}\right.$,

$$
\left.{ }^{\exists} \boldsymbol{g}_{i}{ }^{-} \text {s. t. } \boldsymbol{h} \cdot{ }^{n} \boldsymbol{g}^{-}=0\right\}
$$

この場合， $\boldsymbol{a}_{n+1}$ によって新しく生成される 稜ベクトル $\boldsymbol{g}_{p, q}^{\prime}$ は $\left\{{ }^{n} \boldsymbol{g}_{p}^{-}\right\}$己 $\left\{{ }^{n} \boldsymbol{g}_{q}{ }^{+}\right\}$から 1 本ずつ取り出して作った対に関し， $\{\boldsymbol{h} \mid \boldsymbol{h}$ $\in\left\{{ }^{n} \boldsymbol{h}_{j}\right\},{ }^{\exists} \boldsymbol{g}_{i}{ }^{-}$s. t. $\left.\boldsymbol{h} \cdot{ }^{n} \boldsymbol{g}_{i}{ }^{-}=0\right\}$ の中の独立 な $N-3$ 本の係数べクトルに同時に直交する すべての対について (31)，(32)式で与えられ る.

$$
\hat{\boldsymbol{g}}_{p, q}^{\prime}=\left(\boldsymbol{a}_{n+1} \cdot{ }^{n} \boldsymbol{g}_{q^{+}}\right)^{n} \boldsymbol{g}_{p}{ }^{-}-\left(\boldsymbol{a}_{n+1} \bullet{ }^{n} \boldsymbol{g}_{p}{ }^{-}\right)^{n} \boldsymbol{g}_{q}{ }^{+}
$$

$$
\boldsymbol{g}_{p, q}^{\prime}=\frac{\hat{\boldsymbol{g}}_{p, q}^{\prime}}{\left\|\hat{\boldsymbol{g}}_{p, q}^{\prime}\right\|}
$$

結局,

$$
\left\{{ }^{n+1} \boldsymbol{g}_{i}\right\}=\left\{{ }^{n} \boldsymbol{g}_{i}^{-}\right\} \cup\left\{{ }^{n} \boldsymbol{g}_{i}{ }^{0}\right\} \cup\left\{\boldsymbol{g}_{p, q}^{\prime}\right\}
$$

である.

以上において，最初に解の適当な初期領域が与えら れれば，順次解領域が修正され，求める領域に収束し ていくことになる。このためには，Aの中から互いに 独立な $N-1$ 本の行ベクトル（係数ベクトル）を適当 に抜き出して ${ }^{0} \boldsymbol{h}_{j} ; j \in\{1, \cdots, N-1\}$ とし，乙れに $\boldsymbol{a}_{0}$ を付け加えてできる正方行列の逆行列の符号を変 えたものの列べクトルのうち $\boldsymbol{a}_{0}$ 之直交する $N-1$ 本 を ${ }^{0} \boldsymbol{g}_{i} ; i \in\{1, \cdots, N-1\}$ とすればよい.

このアルゴリズムのフローチャートを Fig. 2 に示 す.

\section{4. 最急降下法による逐次解法の解亡の関連}

本章では，本論文と文献 4) に拈ける手法との関連 について述べる。

文献 4) では $m_{i}$ を逐次修正していき，順位歪み $S$ が零となるような $m_{i}$ を解として与えた. その際, 不感带 $\varepsilon$ を導入し，十分な差をむたない $\varphi_{i j}$ 間の大 小関係に関し断定的な順位づけを行うことを保留し た. この点，順位歪み $S$ に関する記述

『 $\left|\varphi_{i j}-\varphi_{k l}\right| \leqq \varepsilon$

なる関係にある $\varphi_{i j}$ と $\varphi_{k l}$ についてはその差によ って両者間の順位をつけることを保留し $d_{i j}$ のほ
うから決まる $\beta_{i j}$ に準じて $\alpha_{i j}$ を決める』4

を本論文での数值解法に則して表現しなおすと

『 $\left|\varphi_{s t}-\varphi_{q r}\right| \leqq \varepsilon$

なる関係にある $X_{q}, X_{r}, X_{s}, X_{t}$ については $m_{t}$ $m_{s}$ と $m_{r}-m_{q}$ との間の不等号の向きを決定するこ 亡を保留し

$$
\varphi_{u v}-\varphi_{q r}>\varepsilon
$$

なる関係にある $X_{q}, X_{r}, X_{u}, X_{v}$ については

$$
m_{v}-m_{u}>m_{r}-m_{q}
$$

が成立していると見なす』

となり，(11)式と同じ意味をむっているととがわか る.

\section{また，文献 4)の記述}

『との值を固定したまま $m_{i}$ の修正を行い $S$ が零に 収束するかどうか判断する，零に収束しないときは 適当な段階で $m_{i}$ の修正を打ち切り， $\varepsilon$ を適当に増 加させ同様の操作を行い，S が零に収束するまで操 作を続行する.』

は, 本論文 2 章 2 項で $\varepsilon$ の取り扱いについて述べた内 容に対応する.

結局， $\varphi_{i j}$ からの情報の取り出し方は同じではある が，解の求め方において，文献 4)では評価関数 $S$ を, 本論文では連立不等式を用いており，前者が $S=0$ を 満たす解を一つ求めたのに対し，本論文の手法は $S=$ 0 を満たす解を余すととろなく解領域として与えるす のになっている．また，文献 4)では $\boldsymbol{m}$ を逐次細かく 修正していくわけであり，いったん $\boldsymbol{m}$ が本論文でい う解領域の内部に入ってしまえば $S=0$ となって修正 は打ち切られるから, その解は解領域の周辺部に位置 することになる，な执，解領域の代表值としては，領 域中央部の点が適当とも考えられるが, 真の值と解領 域の位置的関係をすっと詳細に知る必要がある．との 点, 解領域の代表值の取り方と精度の議論は今後の課 題であり, 文献 4)の解の質についてもその段階で正 しい評価が可能となろう。

\section{5. 応用 例}

本手法のもつ実用上の効用を検証するため，重さの 一詨比較判断から得られたデータ ${ }^{6)}$ に提案したアルゴ リズムを適用した。

Table 1 は被験者に一対の重りを与え, ごちらが重 いか判断させる実験で一方が他方より重いと判断され た合計回数である.10 個の重りは外見上の差をなく してあり，直示天秤で測った質量が Table 1 の左欄 に示してある. 被験者数はのべ 40 人である. 表中, 対角線について対称の位置にある要素同士はその和が 
Table 1 Frequency on subjective comparison of weights

\begin{tabular}{r|c|ccccccccccc}
\hline \hline mass $g$ & $i$ & $j$ & $X_{1}$ & $X_{2}$ & $X_{3}$ & $X_{4}$ & $X_{5}$ & $X_{6}$ & $X_{7}$ & $X_{8}$ & $X_{9}$ & $X_{10}$ \\
\hline 92.00 & $X_{1}$ & $\cdots$ & 23 & 28 & 39 & 40 & $\cdots$ & $\cdots$ & $\cdots$ & $\cdots$ & $\cdots$ \\
93.00 & $X_{2}$ & & $\cdots$ & 23 & 38 & 40 & 40 & $\cdots$ & $\cdots$ & $\cdots$ & $\cdots$ \\
94.00 & $X_{3}$ & & & $\cdots$ & 38 & 39 & 40 & 40 & $\cdots$ & $\cdots$ & $\cdots$ \\
99.00 & $X_{4}$ & & & & $\cdots$ & 27 & 34 & 36 & 39 & 40 & $\cdots$ \\
100.00 & $X_{5}$ & & & & & $\cdots$ & 30 & 31 & 38 & 40 & 40 \\
102.00 & $X_{6}$ & & & & & & $\cdots$ & 26 & 32 & 36 & 39 \\
103.00 & $X_{7}$ & & & & & & & $\cdots$ & 29 & 35 & 38 \\
105.00 & $X_{8}$ & & & & & & & & $\cdots$ & 26 & 37 \\
107.00 & $X_{9}$ & & & & & & & & & $\cdots$ & 29 \\
109.00 & $X_{10}$ & & & & & & & & & & & \\
\hline
\end{tabular}

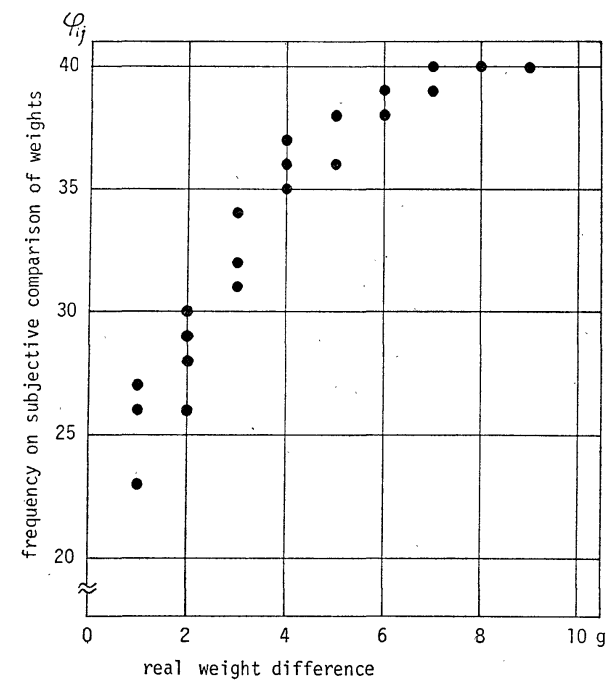

Fig. 3 Band function on subjective comparison of weights

40 になる関係にあるため, 左下半分の数值は省略し てある.

このような結果を帯関数モデルに対応したデータと みなせば，横軸に実際の重さの差を取り Fig. 3 のよ うな幅と非直線性を有する一つの帯関数が得られる。

このデータに本アルゴリズムを適用した結果, 稜ベ クトルは 65 本求められた(注 3 ). また, 必要十分係数 ベクトルは 19 本定められ，それを Table 2 に示す. なお，と*は1であった(注 4 ).

解領域之真の質量との関係を見るために，真の質量 に対応したベクトルを(5),（6)式で正規化し，乙れ と長さ 1 に正規化した必要十分係数ベクトルとの内積

(注 3) 本論文では紙数の都合で表は割愛した. 入手を希望 される読者には,連絡して頂ければ別途送付致します。

(注 4) 計算は東京工業大学総合情報処理センターの HITAC M-200 H で行い，演算時間は 1.8 秒であっ た.
Table 2 Necessary and sufficient coefficient vectors

\begin{tabular}{r|rrrrrrrrrr}
\hline$j$ & \multicolumn{10}{c}{$h_{j}$} \\
\hline 1 & 1 & 0 & -1 & 0 & 0 & 0 & 0 & -1 & 1 & 0 \\
2 & 0 & 0 & 1 & -1 & 0 & -1 & 0 & 0 & 1 & 0 \\
3 & -1 & 1 & 0 & 0 & 0 & 1 & -1 & 0 & 0 & 0 \\
4 & -1 & 0 & 1 & 0 & 1 & -1 & 0 & 0 & 0 & 0 \\
5 & 0 & 0 & 0 & 0 & 0 & 0 & -1 & 1 & 1 & -1 \\
6 & 0 & -1 & 1 & 0 & 0 & 1 & -1 & 0 & 0 & 0 \\
7 & 0 & 0 & 0 & 1 & -1 & -1 & 1 & 0 & 0 & 0 \\
8 & 0 & -1 & 0 & 1 & 1 & 0 & 0 & 0 & -1 & 0 \\
9 & 0 & 0 & 0 & 0 & 1 & 0 & -1 & 0 & -1 & 1 \\
10 & 0 & 1 & 0 & 0 & -1 & 0 & -1 & 0 & 0 & 1 \\
11 & 0 & 0 & 0 & 0 & 0 & 1 & 0 & -1 & -1 & 1 \\
12 & 0 & 0 & 0 & 0 & 0 & -1 & 1 & 1 & -1 & 0 \\
13 & 0 & 0 & 0 & -1 & 1 & 0 & 1 & -1 & 0 & 0 \\
14 & 0 & 0 & 0 & -1 & 0 & 1 & 0 & 1 & 0 & -1 \\
15 & 0 & 0 & 0 & 0 & -1 & 0 & 2 & 0 & -1 & 0 \\
16 & 0 & 0 & 0 & -1 & 2 & -1 & 0 & 0 & 0 & 0 \\
17 & 0 & 0 & 0 & 1 & 0 & -2 & 0 & 1 & 0 & 0 \\
18 & 0 & 0 & 0 & 0 & 0 & 0 & 1 & -2 & 1 & 0 \\
19 & 0 & 0 & 1 & -2 & 0 & 0 & 1 & 0 & 0 & 0 \\
\hline
\end{tabular}

Table 3 Inner products between necessary and sufficient coefficient vectors and scale vectors

\begin{tabular}{|c|c|c|c|c|c|}
\hline \multirow{2}{*}{$j$} & \multicolumn{4}{|c|}{ Inner product } & \multirow{2}{*}{ remark } \\
\hline & (A) & (B) & (C) & (D) & \\
\hline 1. & 0.0 & -0.006 & -0.010 & -0.004 & \multirow{19}{*}{$\begin{array}{l}\text { (A); real scale } \\
\text { (B); } \\
\text { representative } \\
\text { scale of the } \\
\text { proposed } \\
\text { method } \\
\text { (C), (D); } \\
\text { Kobayashi- } \\
\text { Shibata's } \\
\text { method } \\
\text { \#; least value }\end{array}$} \\
\hline 2 & 0.0 & -0.017 & -0.036 & -0.044 & \\
\hline 3 & 0.0 & $-0.004 \#$ & $-0.001 \#$ & -0.002 & \\
\hline 4 & 0.0 & -0.017 & -0.026 & -0.053 & \\
\hline 5 & 0.0 & -0.013 & -0.004 & -0.013 & \\
\hline 6 & 0.0 & -0.006 & -0.009 & $-0.001 \#$ & \\
\hline 7 & 0.0 & -0.014 & -0.012 & -0.005 & \\
\hline 8 & -0.028 & -0.022 & -0.011 & -0.021 & \\
\hline 9 & -0.028 & -0.013 & -0.010 & -0.006 & \\
\hline 10 & -0.028 & -0.031 & -0.032 & -0.005 & \\
\hline 11 & -0.028 & -0.014 & -0.019 & $-0.001 \#$ & \\
\hline 12 & -0.028 & -0.011 & -0.003 & -0.007 & \\
\hline 13 & -0.028 & -0.020 & -0.036 & -0.054 & \\
\hline 14 & -0.028 & -0.011 & -0.003 & -0.010 & \\
\hline 15 & -0.023 & -0.009 & -0.009 & -0.002 & \\
\hline 16 & -0.023 & -0.016 & -0.022 & -0.048 & \\
\hline 17 & 0.0 & -0.011 & -0.002 & -0.008 & \\
\hline 18 & 0.0 & -0.018 & -0.036 & -0.042 & \\
\hline 19 & -0.023 & -0.012 & -0.029 & -0.034 & \\
\hline
\end{tabular}

を求めた．結果を Table 3(A) 亿示す．真值は 9 本の 必要十分係数ベクトルと直交しており，解領域を規定 する凸多面錐の 9 つの辺に含まれている，とてろで， 解は凸多面錐の内点と定義したので，厳密には真值は その解領域に含まれていないことになる。 その理由と して，つぎのととが考えられる。

Fig. 3 つまり質量測定に基づく帯関数については 


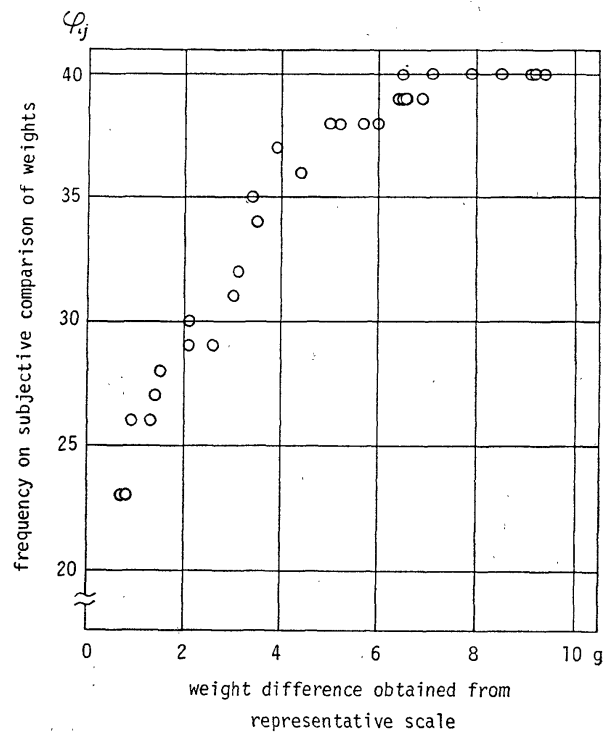

Fig. 4 Band function on subjective comparison of weights reconstructed with representative scale

その横軸 $2 g$ において $\varepsilon_{\max }=4$ となっている． $\varepsilon=4$ として不等式をたてるべきとてろ，

$$
\varepsilon^{*}=1 \neq \varepsilon_{\max }
$$

について解領域が定められたため，解領域が狭まって しまったのである，2章 2 項で述べたように， $\varepsilon^{*}$ は 『連立不等式が解をむつ最小の 有限性, 離散性によりときと.して $\varepsilon_{\max }$ より小さい で解が存在してしまう．とのととは後述する Table 4 (B)の正規化平均ベクトルの值を, 試料の質量に関す る平均値と分散に合せて読み換えた質量值に基づい て，帯関数を再構成した Fig. 4 を見るとよくわか る.すなわち，乙の応用例においては Fig. 3 のデー タが全体的に微小に動いた状態に対応したすのについ て解が求められている.なお， $\varepsilon を \varepsilon^{*}$ より少し大き くして不等式をたてれば，解領域はそれにつれて広が り，真值をより確実に含むようになるが，解領域が広 がる分，あいまいさむ大きくなる， $\varepsilon_{\max }$ を正確に求 める手法の開発が望まれるが，一般に有限個のデータ から求めるには限界があるとも考えられ，今後の課題 である.

つぎに，ほかの方法による結果と精度の比較を行う ために，解領域の代表值として正規化平均ベクトル $\boldsymbol{g}_{A}$ を次式で定義した.

$$
\begin{aligned}
& \hat{\boldsymbol{g}}_{A}=\frac{1}{r_{K}} \sum_{i=1}^{r_{K}} \boldsymbol{g}_{i} \\
& \boldsymbol{g}_{A}=\frac{\hat{\boldsymbol{g}}_{A}}{\left\|\hat{\boldsymbol{g}}_{A}\right\|}
\end{aligned}
$$

\begin{tabular}{|c|c|c|c|c|}
\hline \multirow{2}{*}{$\frac{\text { real scale }}{(\mathrm{A})}$} & \multicolumn{3}{|c|}{ reconstructed scale } & \multirow{2}{*}{ remark } \\
\hline & (B) & (C) & (D) & \\
\hline-0.472 & -0.459 & -0.457 & -0.439 & \multirow{11}{*}{$\begin{array}{l}\text { (B); } \\
\text { represent } \\
\text { scale of } \\
\text { proposed } \\
\text { method. } \\
\text { (C), (D); } \\
\text { Kobayashi- } \\
\text { Shibata's } \\
\text { method. }\end{array}$} \\
\hline-0.416 & -0.415 & -0.415 & -0.415 & \\
\hline-0.360 & -0.374 & -0.388 & -0.389 & \\
\hline-0.079 & -0.096 & -0.084 & -0.083 & \\
\hline-0.023 & -0.017 & -0.016 & -0.044 & \\
\hline 0.090 & 0.101 & 0.104 & 0.112 & \\
\hline 0.146 & 0.153 & 0.149 & 0.140 & \\
\hline 0.259 & 0.272 & 0.287 & $0: 287$ & \\
\hline 0.371 & 0.346 & 0.337 & 0.330 & \\
\hline 0.484 & 0.490 & 0.483 & 0.501 & \\
\hline $\begin{array}{l}\text { sum of } \\
\text { square } \\
\text { difference }\end{array}$ & 0.0017 & 0.0033 & 0.0058 & \\
\hline
\end{tabular}

Table 4 Reconstructed scales and comparison of goodness of fit to real scale

今回のデータから求まった $\boldsymbol{g}_{A}$ を Table $4(\mathrm{~B})$ 飞示 す. Table 4(C)，(D) は，文献 4)の方法を用いて， 2 種の異なった初期值から構成した間隔尺度である。 Table 4 では，真值と再現された間隔尺度との差の 2 乗和が合せて示さ机ており，それらを比較すると本ア ルゴリズムの有効さが理解できる．今回の例のよう に，真值が解領域の周辺部にある場合，(C)，(D)の 方法では初期值の与え方により再現性のよさが影響さ れる。

なお， Table 3(B)〜 (D) には, Table 4(B)〜 (D) に対応するベクトルと, Table 2 の必要十分係数べク トルを正規化したむのとの内積を示してある. (B)に 比べ，(C)，(D)は值のバラッキが大きく，（B）は解 領域のより中央部に，(C)，(D)は 4 章で指摘したと おり解領域の周辺部位置しているととがわかる。な 押, Table 3(C)〜 (D) 亿は, 最す近くに位置する辺 に対応する係数ベクトルとの内積に印を付けてある.

\section{6. むす び}

官能検查などによく用いられる一対比較データのた め新しい数值処理法を提案した。

この方法は, 帯関数モデルを仮定しているため, 従 来一般的に一対比較法で扱われているほとんぞのデー 夕に適用でき，特に比較判断に非直線性がある場合に 最む大きな効果を発揮する。また，すべての比較対に 対する判断結果を心ずしあ必要とせず，かう判断結果 に入っているあいまいさやバラッキの程度をこの大き さから知るととができるなど，文献 4) で提案された 手法のむつ特長と有效性をそのまま共有すると同時 に，带関数モデルを前提とする範囲でデータのもつす べての情報を解領域の形式であますところなく尺度構 
成化することができる点に大きな意味を有している. 今後, 解領域の大きさや代表值の与え方の検討によ り，本手法のむつ効用についてさらにきめ細かい議諭 ができると考えている。

\section{参 考 文 献}

1) 岡本暘之助 : 感覚計測, 計測と制御, 15-1, 146/150(1976)

2) 小林 彬：検査の機器計測化への諸問題, 電気学会雑誌 100-9, 827/834 (1980)
3）日科技連官能検査委員会編：新版官能検査ハンドブッ ク，241/570，日科技連出版社 (1973)

4) 小林 涁, 芝田 勉: 一対比較のための非計量的手法 計測自動制御学会論文集，14-2，189/195（1978）

5) A. J. Goodman and A. W. Tucker: Polyhedral Convex Cones, Linear Inequalities and Related Systems, 19/40, Princeton University Press (1956)

6) 諏訪部和之：順序構造之計測，東京工業大学制御工学科 修士論文 (1976)

7）小林 彬，村上瑞夫：非計量一対比較法の解領域につい て，第 17 回 SICE 学術講演会予稿集，3512 (1978) 